\title{
PIOTR CHOMIK
}

Białystok

\section{TRZEJ WILEŃSCY MĘCZENNICY I POCZĄTKI MONASTERU ŚW. TRÓJCY W WILNIE}

Jeden z najważniejszych monasterów w Wielkim Księstwie Litewskim monaster św. Trójcy w Wilnie został najprawdopodobniej założony w połowie XIV w. (pomiędzy 1347 a 1350 r.), za sprawą drugiej żony księcia Olgierda, księżniczki Julianny Twerskiej ${ }^{1}$. U podstaw założenia monasteru legła śmierć tzw. Trzech Wileńskich Męczenników, Antoniego, Jana i Eustachego. Zostali oni straceni pomiędzy styczniem a grudniem 1347 r., a na miejscu ich kaźni ufundowano monaster.

Jednak dokładna data ufundowania monasteru wileńskiego jest nieznana, a latopisy informowały o obecności mnichów „wiary grecko-ruskiej” w Wilnie w roku $1391^{2}$. Być może chodziło właśnie o mnichów wileńskiego klasztoru św. Trójcy. Zachowane po dzień dzisiejszy dokumenty archiwalne dotyczące monasteru św. Trójcy w Wilnie odnoszą się do wieku XVI.

Związek założenia monasteru św. Trójcy w Wilnie z męczeńską śmiercią trzech wileńskich męczenników wymaga bliższego omówienia. Analizując zachowane do dzisiaj teksty zawierające opis męczeństwa, litewski badacz D. Baronas zauważył, że nie ma w nich stwierdzenia, wprost, że cerkiew św. Trójcy na cześć męczenników została zbudowana w Wilnie. Zgodnie z zachowanymi żywotami świętych męczenników wileńskich książę Olgierd zgodził się jednak dać miejsce pod budowę cerkwi, inne niż to, o które prosili wileńscy prawosławni. W późniejszych źródłach miejsce, na którym zbudowano cerkiew św. Trójcy określa się

1 Litewskie Państwowe Archiwum Historyczne, f. 605, op. 6, nr 2, k. 122.

2 Ю. Шчербицкий, Виленский свято-троицикий монастьрь, Вилна 1896, s. 17. 
mianem „wzniesienia”’. Ponadto fakt, że słowo „trójca” zarówno w greckim jak i serbskim języku (także w cerkiewnosłowiańskim - P. Ch.) oznacza nie tylko św. Trójcę, ale także grupę trzech osób, mógł mieć wpływ na wybór wezwania cerkwi wzniesionej ku chwale męczenników.

Jeszcze w latach 20. XX w. K. Chodynicki odrzucił historyczność męczeństwa trzech wileńskich świętych ${ }^{4}$. Twierdził on m.in., że o męczeństwie tym nie wspominają źródła pochodzące z obszaru WKL (np. Kronika Bychowca czy Kronika Stryjkowskiego) oraz że legenda o męczeństwie była „sztucznie” podtrzymywana przez mnichów klasztoru św. Ducha w Wilnie oraz metropolitę Józefa Siemaszkę (w XIX w.). Powoływał się też na XVII-wieczne źródła rzymskokatolickie i unickie zawierające wiadomości o trzech wileńskich męczennikach ${ }^{5}$, co miałoby wskazywać na późniejsze pochodzenie kultu. Jednocześnie przyznawał, że XV-wieczne latopisy z terenu Rusi Moskiewskiej - Jermoliński, Sofijski i Woskresienski informują o fakcie męczeństwa. Twierdził jednak, że kroniki te pisane były w duchu nienawiści do Polski i dynastii Jagiellonów i stąd wywodził ich tendencyjność i małą wiarygodność. Wątpliwości Chodynickiego budziła również kwestia kanonizacji męczenników wileńskich. Odrzucił on możliwość kanonizacji męczenników przez metropolitę kijowskiego Aleksego (1354-1378) w 1364 r., twierdząc, że zostali on kanonizowani przez sobór w Moskwie w 1547 r., a zatem był to kult moskiewski, obcy tradycji prawosławia w WKL.

Wątpliwości dotyczące świadectw kronikarskich o męczeństwie poddał krytyce D. P. Ogickij ${ }^{6}$. Wskazał niekonsekwencje w rozumowaniu Chodynickiego, oraz stwierdził, że współczesne wydarzeniom latopisy państw ościennych nie mówią nic o męczennikach wileńskich. Nie mówią, bo nie mogą mówić. Na przykład latopis nowogrodzki jest doprowadzony do roku 1333 i chociaż zawiera późniejsze dopiski, dotyczą one wyłącznie spraw lokalnych. Podobnie rzecz ma się z latopisami pskowskimi, o których wiadomo, że ich najstarsze wersje pochodzą z lat 60 . XV w. Nie były one zatem współczesne w odniesieniu do wileńskiego męczeństwa. Ogickij krytykuje także stwierdzenia Chodynickiego dotyczące datowa-

3 Biblioteka Litewskiej Akademii Nauk (dalej: BLAN), F. 19-147; J. Fijałek, Opisy Wilna aż do połowy wieku XVII-go, „Ateneum Wileńskie,” 1924, nr 5-6, R. 2, s. 142; Д. Баронас, По поводу титературной истории Мучения трех виленских мучеников, „Krakowsko-Wileńskie Studia Slawistyczne", t. 3, red. W. Stępniak-Minczewa i A. Naumow, Kraków 2001, s. 79-80.

4 K. Chodynicki, Geneza i rozwój legendy o trzech męczennikach wileńskich, „Ateneum Wileńskie” 1927, nr 13, R. 4, s. 417-451.

5 Acta Sanctorum, Aprilis, t. 2, Parisis 1866, s. 265; Д. Баронас, op. cit., s. 92.

6 Д. П. Огицкий, К истории виленских мучеников, www.krotov.info/history/14/2/1994ogiz.html dostęp: 26.11.2009. 
nia na wiek XVI wspomnianych powyżej latopisów: Jermolińskiego, Sofijskiego i Woskresienskiego. Jeżeli natomiast chodzi o latopisy litewskie - supraski, słucki Ogickij stwierdził, że ich źródła tkwią w wieku XV, i w zależności od nich znajduje się też Kronika Bychowca. Z tego też względu nie mogą mówić o męczennikach, bowiem $\mathrm{w}$ ogóle bardzo mało mówią o sprawach litewskich $\mathrm{z}$ okresu poprzedzającego panowanie Witolda. Jedyną natomiast kroniką mówiącą o wileńskich męczennikach jest Kronika Litewska i Żmudzka (koniec XVI - pocz. XVII w.), jednak znana ona jest w wersjach pochodzących z wieku XVIII

Istotniejsze są uwagi Ogickiego dotyczące kanonizacji wileńskich męczenników, bowiem data i miejsce kanonizacji mają ogromne znaczenie dla ustalenia ówczesnej - XIV-wiecznej - pozycji międzynarodowej Wielkiego Księstwa Litewskiego i miejsca w nim wyznania prawosławnego.

Najważniejszym argumentem przytaczanym przez Ogickiego jest fakt, że w dokumentach soboru moskiewskiego z 1547 r. w ogóle nie ma mowy o męczennikach wileńskich. Wymienia ich jedynie lista świętych ułożona po $1549 \mathrm{r}$. Oznacza to, że nie zostali oni wówczas kanonizowani, a jeśliby tak było, oznaczałoby to, że ich kult rozpoczął się dopiero w połowie XVI w. ${ }^{8}$

Kult świętych męczenników wileńskich był rozpowszechniony w XVI w. na obszarze WKL jeszcze przed 1547 r. o czym świadczą zachowane w Bibliotece Litewskiej Akademii Nauk w Wilnie księgi liturgiczne. Takim rękopisem są: pochodzący z końca XV w. prolog obejmujący miesiące marzec-sierpień ${ }^{9}$ oraz XVI-wieczny prolog z monasteru w Supraślu, zawierający żywot męczenników wileńskich pod datą $14 \mathrm{kwietnia}^{10}$. Inne zachowane rękopisy - żywoty świętych - pochodzące z przełomu XV i XVI w. umieszczają żywot męczenników wileńskich po wrześniu ${ }^{11}$. Kolejny rękopis prologu obejmujący miesiące wrzesień-luty, datowany na rok 1512, zawiera żywot męczenników wileńskich pod datą 14 stycznia ${ }^{12}$. Oficjum dla uczczenia w tradycji rękopiśmiennej Wielkiego Księstwa Litewskiego znajdowało się również $\mathrm{w}$ terminie trzeciej niedzieli przed Bożym Narodzeniem, jak zaświadcza przywoływana już minieja (kodeks) z monasteru św. Trójcy w Słucku, przechowywany również w Wilnie. Uwagi jakimi opatrzo-

7 Д. П. Огицкий, op. cit.; H. Paprocki, Wileńscy męczennicy, „Wiadomości Polskiego Autokefalicznego Kościoła Prawosławnego" 1991, R. 21, z. 3, s. 9.

8 Д. П. Огицкий, op. cit.; Н. Paprocki, op. cit., s. 9.

9 BLAN, F. 19-100; Д. Баронас, op. cit., s. 76, 90.

10 BLAN, F. 19-98; Д. П. Огицкий, op. cit.; H. Paprocki, op. cit., s. 9.

11 BLAN, F. 19-76, F. 19-102; Д. Баронас, оp. cit., s. 76; Д. П. Огицкий, op. cit.; H. Paprocki, op. cit., s. 9.

12 BLAN, F. 19-95; Д. Баронас, op. cit., s. 76, 90; Д. П. Огицкий, op. cit.; Н. Paprocki, op. cit., s. 9. 
ny jest tekst służby świadczy o jej greckim, bizantyjskim pochodzeniu, chociaż D. Baronas twierdzi, że jest to redakcja południowosłowiańska ${ }^{13}$.

Dymitrij P. Ogickij pisał też o rękopisie XV-wiecznego prologu serbskiego przechowywanego w Belgradzie, a zawierającego żywot męczenników wileńskich pod datą 16 grudnia, oraz o znajdujących się w zbiorach muzealnych $\mathrm{XV}$-wiecznych przedmiotach, zawierających napisy dotyczące kultu świętych męczenników wileńskich ${ }^{14}$.

Wspomniany prolog z monasteru w Słucku jak i prolog z Belgradu w swych fragmentach mówiących o wileńskich męczennikach muszą być charakteru południowego, bowiem określają Wielkie Księstwo Litewskie jako kraj wielkich mrozów ${ }^{15}$. W żadnym wypadku nie mógł pisać tak mieszkaniec Moskwy, dla którego chłody litewskie nie mogły być czymś osobliwym.

Istnieje też żywot męczenników wileńskich przechowywany w lwowskiej bibliotece Ukraińskiej Akademii Nauk. Żywot ten zawarty jest w XVI-wiecznej miniei monasteru uniewskiego ${ }^{16}$. Znane są również rękopisy cerkiewnosłowiańskie, zawierające opisy męczeństwa wileńskich świętych przechowywane w Bibliotece Narodowej w Warszawie. Najstarszy z rękopisów pochodzi z 1555 r., najmłodszy najprawdopodobniej z wieku XVII ${ }^{17}$.

Argumenty za historycznością postaci św. męczenników wileńskich przedstawił również John Meyendorff.

Fakty dotyczące wileńskich męczenników podane są w ich słowiańskim żywocie zredagowanym przez anonimowego Serba oraz w panegiryku (enkomium) greckim, ułożonym przez znaczącego dygnitarza patriarchatu konstantynopolitańskiego, Michała Balsamona. Poza tym wizerunki trzech męczenników występują, obok portretów książąt bizantyjskich i moskiewskich, na zabytku dato-

13 BLAN, F. 19-147; Д. Баронас, op. cit., s. 75; Д. П. Огицкий, op. cit.; A. Naumow, Wiara $i$ historia. Z dziejów literatury wschodniostowiańskiej na ziemiach polsko-litewskich, Kraków 1996, s. 61. Zainteresowanych szczegółowymi informacjami o tekście tego nabożeństwa, poświęconego trzem męczennikom wileńskim, odsyłam do pracy Ogickiego, który omawia je bardzo szczegółowo.

14 Д. П. Огицкий, op. cit. Informacje o prologu serbskim Ogickij powtarza za: М. Сперанский, Сербское житие литовских мучеников, Москва 1909. Speranski jako pierwszy podjął próbę ustalenia daty powstania żywotu świętych męczenników wileńskich, a niektóre z jego wywodów do dzisiaj są aktualne. Według najnowszych ustaleń wydany przez Speranskiego żywot męczenników znajdował się w serbskim odpisie prologu „Stisznego” z XV w. Prolog ten przepadł podczas bombardowania Belgradu w 1941 r.; Д. Баронас, op. cit., s. 74.

Д. П. Огицкий, op. cit.; Н. Paprocki, op. cit., s. 10

16 Д. Баронас, op. cit., s. 75.

17 Ibidem, s. 76; Rękopisy cerkiewnosłowiańskie w Polsce. Katalog, opr. A. Naumow, A. Kaszlej, współpr. E. Naumow i J. Stradomski, Kraków 2004, s. 274, 282-284, 287-288, 291. 
wanym na początek XV w., „wielkim sakkosie” metropolity Focjusza ${ }^{18}$. Obecność wizerunków męczenników wileńskich na metropolitalnej szacie liturgicznej przypominała, że ich kult związany był z próbami podzielenia metropolii kijowskiej i rzucenia wyzwania prestiżowi Bizancjum. Tak było w czasach Olgierda, tak też stało się w czasach Witolda, kiedy to Focjusz musiał toczyć walki o stolec metropolitalny z Grzegorzem Camblakiem, popieranym przez księcia litewskiego. Na sakkosie wyrażona została zatem ideologia polityczna i cerkiewna. Po tajemniczym zniknięciu Grzegorza Focjusz wielokrotnie odwiedzał Wielkie Księstwo Litewskie oraz ustanowił stosunki z Witoldem. Tym samym odrestaurowane zostało bizantyjskie, cerkiewne status quo.

Żywot słowiański zwracał uwagę na fakt, że dwaj młodzi Litwini, bracia Kruglec - ochrzczony jako Antoni i Nieżyl - ochrzczony jako Jan, po przyjęciu chrześcijaństwa odrzucili zwyczaje litewskie sprzeczne z ich nową wiarą i chociaż początkowo byli skłonni przyjąć warunki wielkiego księcia Olgierda i wyznawać chrześcijaństwo jedynie „prywatnie”, to ostatecznie odmówiwszy warunkom postawionym przez wielkiego księcia zostali aresztowani i skazani na śmierć przez powieszenie. Trzeci męczennik, Kumec - po ochrzczeniu Eustachy, również zamanifestował swoje nowe przekonania religijne, co spotkało się i tym razem z gwałtowną reakcją księcia; Eustachego torturowano i również stracono przez powieszenie. W konkluzji autor żywotu podaje, że po śmierci trzech męczenników nikt już w Wilnie nie został stracony za praktykowanie chrześcijaństwa. Syn Olgierda (żywot nie podaje który - P. Ch.) ułatwił przechowanie relikwii Eustachego i sam wielki książę przychylił się do prośby domagających się ziemi dla zbudowania cerkwi ku czci męczenników ${ }^{19}$. Rzecznikiem proszących chrześcijan mogła być żona Olgierda, Julianna.

Omawiając enkomium Michała Balsamona, Meyendorff zauważa, iż jest „sprawą wyjątkową, że greckie źródło hagiograficzne wspomina świętych słowiańskich". Pojawienie się świętych z innego obszaru Meyendorff tłumaczy ukształtowaniem się w Bizancjum nowego uniwersalistycznego poglądu głoszącego jedność i solidarność narodów prawosławnych. Pogląd ten został oficjalnie uznany przez

18 J. Meyendorff, Trzej wileńscy męczennicy. Bizancjum i Litwa w XIV wieku, „Wiadomości Polskiego Autokefalicznego Kościoła Prawosławnego", R. 20, z. 3, Warszawa 1990, s. 3-4; Д. П. Огицкий, op. cit.; Sakkos to zdobiona tunika będąca szatą cesarzy bizantyjskich. Wcześniej był to strój pokutny. Następnie nosili ją patriarchowie, a także niektórzy biskupi. Dzisiaj jest szatą liturgiczną wszystkich biskupów prawosławnych, Ch. Walter, Sztuka i obrządek Kościoła bizantyjskiego, Warszawa 1992, s. 326-327.

19 J. Meyendorff, op. cit., s. 4-5. 
patriarchów Kalistosa I i Filoteusza Kokkinosa (1364-1376). Enkomium o trzech męczennikach wileńskich jest tego wyrazem ${ }^{20}$.

Tekst grecki jest dłuższy od żywotu słowiańskiego oraz podaje bardziej precyzyjne dane dotyczące męczenników; należeli oni do odrębnego narodu litewskiego, Jan był starszym bratem Antoniego. Autor źródła nazywa ich „ruskimi”, „ale nie z tych, którzy na początku przybyli do nas na statku, ale z tych spośród nich, którzy zwani są Litwinami i czcicielami ognia”. W zakończeniu jest też mowa o cudach dokonywanych w Wilnie i Konstantynopolu. Sugeruje ono [enkomium], że tekst ten został ułożony pod koniec okresu drugiego zasiadania na tronie patriarszym przez Filoteusza, który został określony jako ten, który „pierwszy czcił trzech świętych". Jednakże tytuł enkomium określa Michała Balsamona jako retora Wielkiej Cerkwi, którą to funkcjępełnił on latach 1390-1394. Najprawdopodobniej do tego okresu należy odnieść powstanie enkomium ${ }^{21}$. Krótki okres pomiędzy śmiercią męczenników a powstaniem opowieści o męczeństwie może sugerować wierność opisu.

Darius Baronas zwrócił uwagę na te fragmenty opisu męczeństwa, które można potwierdzić w innych współczesnych bądź późniejszych źródłach. Po pierwsze, zwracają uwagę paralele pomiędzy opisem męczeństwa a listem późniejszego metropolity kijowskiego Cypriana do świętego Sergiusza z Radoneża. W tekście męczeństwa mówi się o oswobodzeniu dużej grupy jeńców. Jeszcze M. Speranski przypuszczał, że byli to poddani moskiewscy, którzy dostali się do niewoli podczas licznych pochodów wielkiego księcia Olgierda na Moskwę. W liście do św. Sergiusza Cyprian twierdzi, że w czasie swego pobytu na Litwie wyzwolił wielu jeńców „z gorzkiej niewoli”. Niektórzy z nich spędzili na Litwie dwa i pół roku. Moskiewscy jeńcy prosili Olgierda o zgodę na budowę cerkwi. Zgodę taką uzyskali i cerkiew wkrótce powstała. Oczywiście działania te mogli podjąć jedynie jeńcy obdarzeni przez Olgierda wolnością na terenie WKL. Wiadomo, że Litwini bardzo niechętnie wypuszczali jeńców. Należy zatem przypuszczać, że rzeczywiście ogromną rolę $\mathrm{w}$ tej sprawie, jak i w sprawie budowy cerkwi, odegrał Cyprian ${ }^{22}$. Taki rozwój sytuacji mógł sprzyjać nowemu otwarciu w polityce zagranicznej Olgierda.

Na podstawie przytoczonych danych źródłowych Meyendorff stwierdził, że kult męczenników zaczął się bezpośrednio po ich śmierci oraz że należy go rozumieć, nie tylko w kategoriach religijnych, ale także politycznych. Antoni, Jan i Eustachy zostali zamęczeni, ponieważ odrzucili możliwość dostosowania

\footnotetext{
20 Ibidem, s. 6.

21 J. Meyendorff, op. cit., s. 6-7; Д. Баронас, op. cit., s. 78; Д. П. Огицкий, op. cit.

22 Д. Баронас, op. cit., s. 78-79.
} 
się do zewnętrznych uwarunkowań na pogańskim dworze Olgierda: nalegali na konieczność publicznego okazania swej wierności wschodniemu chrześcijaństwu poprzez noszenie bród i powstrzymywanie się od jedzenia mięsa w poście. W epoce, gdy Wielkie Księstwo Litewskie prowadziło stałą wojnę z Wielkim Księstwem Moskiewskim kult trzech prawosławnych męczenników z Wilna stanowił (mógł stanowić) dla Olgierda otwarte niebezpieczeństwo ${ }^{23}$. Dlatego też w latach kolejnych Olgierd starał się na nowo ułożyć swoje stosunki z Państwem Moskiewskim, Bizancjum oraz uregulować status prawosławnych mieszkańców swojego państwa. Temu celowi służyła też kanonizacja męczenników wileńskich.

Omawiane przez Meyendorffa źródła dotyczące męczenników nie mówią nic o ich kanonizacji przez metropolitę Aleksego, który aż do 1370 r. prowadził politykę wyraźnie antylitewską i promoskiewską. Jeżeli kanonizacja miała miejsce w 1364 r., może być ona rozumiana jako gest głoszący, że Olgierd, „prześladowca chrześcijan", nie może być godnym kandydatem do pierwszoplanowej pozycji na Rusi. Do takiej roli Olgierd pretendował, również poprzez dążenie do objęcia kontrolą - jak pisał Meyendorff - „potężnego Kościoła prawosławnego w swoim państwie"24.

Realizując ten cel Olgierd rozpoczął starania o reaktywację metropolii litewskiej, wakującej od śmierci metropolity Teofila około 1330 r. Olgierd doskonale rozumiał, że dopóki rezydencja metropolity „całej Rusi” znajdować się będzie w Moskwie, WKL nie wzmocni swego autorytetu wobec licznych książąt ruskich zamieszkujących jego rozległy obszar.

W 1354 r. reaktywacja metropolii litewskiej stała się faktem. Panujący wówczas cesarz Jan VI Kantakuzen doprowadził wcześniej do likwidacji metropolii halickiej jednak na skutek namów Olgierda i innych nieznanych nam dzisiaj przyczyn zmienił swoje stanowisko i zgodził się reaktywować drugą w państwie polsko-litewskim metropolię. A. Mironowicz twierdził, że wpływ na zmianę stanowiska cesarza miała śmierć w 1353 r. obrońcy jedności metropolii kijowskiej, Teognosta. Ponadto jego następcą na stolcu metropolitalnym miał zostać lojalny wobec Wilna metropolita Teodory. Został on wyświęcony na to stanowisko przez patriarchę tyrnowskiego Teodozjusza II. Jednakże za ten czyn został on potępiony przez patriarchę Konstantynopola Kalistosa I. W 1354 r. kiedy kolejny patriarcha carogrodzki Filoteusz wyświęcił na metropolitę kijowskiego i włodzimierskiego

23 J. Meyendorff, op. cit., s. 8.

24 Ibidem. Jednak, jak przyznaje ten autor, data $1364 \mathrm{r}$. pochodziła z błędnego odczytania roku przeniesienia relikwii do Konstantynopola w 1374 r. podanej w serbskiej wersji żywotu, ibidem, s. 6 . 
Aleksego oraz potępił Teodoryta, do Konstantynopola przybyła delegacja litewska w sprawie reaktywowania metropolii ${ }^{25}$.

$\mathrm{Na}$ skutek jej starań dla ziem ruskich wyświęcono drugiego metropolitę o imieniu Roman. Był on szwagrem księcia Olgierda, jednak nie jest pewne czy był bratem jego pierwszej czy drugiej żony. Zarówno Roman jak i Aleksy zostali wyświęceni w tym samym 1354 r. i w związku z tym kronikarz ruski napisał: „W tymże 1354 roku powstało zamieszanie na metropolii, jakiego przedtem nie było na Rusi: patriarcha w Carogrodzie wyświęcił dwóch metropolitów na całą ziemię ruską - Aleksego i Romana. I była między nimi wielka wrogość”26. Powodem starań Olgierda o reaktywowanie metropolii litewskiej była chęć odebrania książętom moskiewskim wpływu na cerkiew ruską. W Konstantynopolu natomiast miano nadzieję na schrystianizowanie Litwy ${ }^{27}$.

Konflikt pomiędzy metropolitami przeciągał się. W latach 1355-1356 obaj metropolici ponownie przebywali w Konstantynopolu, gdzie udowadniali swoje prawa do zarządzania Cerkwią na ziemiach państwa polsko-litewskiego. Faktem jest, że Roman kontrolował znaczącą część Rusi, znajdującą się pod władzą Olgierda, włączając w to Kijów, Briańsk i Twer. W końcu Kalistos I, jak ponownie zajął tron patriarszy, wespół z synodem określił granice metropolii litewskiej: w jej skład weszły nie tylko eparchie włączone za czasów Gedymina (Połock, Turów, ale też Mała Ruś, czyli eparchie halicka i wołyńska). W ten sposób osiągnięto porozumienie, na mocy którego Aleksy został uznany metropolitą kijowskim, a Roman litewskim z o wiele większym zakresem władzy ${ }^{28}$.

Synod patriarszy nie zakończył sporu między metropolitą Aleksym a Romanem. Nadal trwał spór o siedzibę metropolii kijowskiej. Po powrocie z Konstantynopola w Kijowie zatrzymał się Roman. Miało to znaczenie prestiżowe bowiem oznaczało władzę nad całą Rusią ${ }^{29}$. Spór zakończyła dopiero śmierć Romana w 1362 r. Wówczas patriarcha Kalistos wznowił jedność metropolii kijowskiej na czele z metropolitą Aleksym.

Wskutek walk o tron patriarszy w Konstantynopolu patriarcha Kalistos stracił swój urząd na rzecz Filoteusza w 1364 r. Poparł wówczas Aleksego, jako metropolitę kijowskiego i całej Rusi. Dopiero skarga Olgierda, wystosowana

25 A. Mironowicz, Kościót prawosławny w państwie Piastów i Jagiellonów, Białystok 2003, s. 128-129.

26 Cytat za: ibidem, s. 130.

27 Ibidem.

28 И. Мейендорф, Византия и Московская Русь, Парис 1990, s. 204; A. Mironowicz, op. cit., s. 131.

29 И. Мейендорф, Византия..., s. 204-205; A. Mironowicz, op. cit., s. 131. 
w 1370 r. do Konstantynopola, w której książę twierdził, że jest niesprawiedliwie traktowany przez Aleksego zmieniła sytuację. Patriarcha Filoteusz nakazał metropolicie nawiązanie z Olgierdem dobrych stosunków, podobnych do tych, „jakie ma z innymi książętami”. Wiedząc, że wszystkie dzieci wielkiego księcia Litwy są już wyznania prawosławnego, patriarcha, być może, miał nadzieję, że nawróci się sam Olgierd. Rezultatem nakazu patriarszego była pozytywna reakcja Olgierda, i w efekcie zakończenie prowadzonych właśnie działań wojennych przeciwko Moskwie ${ }^{30}$.

W tak sprzyjających okolicznościach został zredagowany słowiański żywot męczenników wileńskich. Fragmenty żywotu mówiące o nowo ochrzczonych synach Olgierda, przechowujących wraz z innymi wiernymi relikwie męczenników, wskazują skąd wypłynęła inicjatywa przeniesienia relikwii do Konstantynopola. W 1373 r. wysłannik patriarchy Filoteusza, bułgarski mnich Cyprian, udał się na Litwę i osiągnął tam porozumienie z Olgierdem co do przyszłości Kościoła prawosławnego na terytorium Wielkiego Księstwa Litewskiego. Cyprian brał też udział w wydarzeniach dyplomatycznych dotyczących Moskwy, Tweru i stosunków z nimi Konstantynopola. Charakterystyczne jest to, że również w 1373 r. porozumienie osiągnęli kniaź twerski Michał i moskiewski Dymitr kończąc wzajemne spory o władzę na obszarze księstwa włodzimierskiego.

Po powrocie do Carogrodu Cyprian został wyświęcony przez patriarchę Filoteusza na metropolitę Kijowa, Rusi i Litwy z prawem sukcesji po śmierci Aleksego. Nominacja ta wskazywała, że Konstantynopol gotów był podtrzymywać jedność kościelną Moskwy i Wielkiego Księstwa Litewskiego oraz gwarantować na tym obszarze równe traktowanie ludności wyznania prawosławnego ${ }^{31}$.

Biorąc te argumenty pod uwagę Meyendorff wskazał, że przeniesienie relikwii męczenników wileńskich do Konstantynopola przez ręce Cypriana i przyjęcie ich przez patriarchę Filoteusza odzwierciedlało plany polityki cerkiewnej Bizancjum w tym okresie. Polityka dążyła do umocnienia i skonsolidowania przyszłości Kościoła prawosławnego w Wielkim Księstwie Litewskim. Inicjatorem kanonizacji był patriarcha Filoteusz, a kanonizacja miała miejsce w 1374 r. ${ }^{32}$ Oznacza to, że kanonizacja męczenników wileńskich oraz ich kult, mimo początkowo nieprzychylnej postawy dworu litewskiego, wyraźnie oznaczały, z jednej strony wzmocnienie pozycji Olgierda - pozytywnie mówią o nim autorzy obu wersji żywotów

30 J. Meyendorff, Trzej wileńscy męczennicy..., s. 9.

31 И. Мейендорф, Византия..., s. 243-244.

32 J. Meyendorff, Trzej wileńscy męczennicy..., s. 10; Д. Баронас, op. cit., s. 78; H. Paprocki, op. cit., s. 10-11; Д. П. Огицкий, op. cit. 
męczenników - w stosunkach z Moskwą i Bizancjum, a z drugiej, poparcie udzielone przez patriarchat konstantynopolitański prawosławiu w Wielkim Księstwie Litewskim wobec pogańskiego władcy.

Monaster św. Trójcy w Wilnie już w wieku XV odgrywał znaczącą rolę w samym mieście stołecznym jak i na całym obszarze WKL. Wiadomo, że $\mathrm{w}$ wieku tym istniała drewniana cerkiew monasterska, przebudowana na początku wieku XVI ${ }^{33}$. U schyłku XV w. archimandrytą monasteru wileńskiego był Makary, wybrany w 1494 r. metropolitą kijowskim.

Makary archimandrytą wileńskim został około 1472 r. Jednocześnie sprawował pieczę nad wszystkimi działającymi monasterami Wielkiego Księstwa Litewskiego. Funkcję tę nadał mu ówczesny metropolita kijowski Symeon. W okresie sprawowania urzędu archimandryty przez Makarego monaster św. Trójcy przeżywał okres rozkwitu. Zbudowano dom, w którym nocowali pielgrzymi, podniesiono dyscyplinę wśród mnichów. Wiadomo, że jeszcze przed oficjalnym objęciem katedry kijowskiej, Makary, jako archimandryta wileńskiego monasteru św. Trójcy, był obecny podczas zaślubin księżniczki moskiewskiej Heleny z wielkim księciem litewskim Aleksandrem ${ }^{34}$.

Archimandryta Makary był wymieniany również jako sygnatariusz listu metropolity Misaela do papieża Sykstusa IV z 14 marca 1476 r. w sprawie realizacji postanowień unii florenckiej na obszarze Wielkiego Księstwa Litewskiego i ziem ruskich wchodzących w skład Rzeczypospolitej. Najnowsze badania wskazują jednak na nieautentyczność tego dokumentu ${ }^{35}$. Już J. Fijałek sugerował, że powodem umieszczenia $\mathrm{w}$ dokumencie archimandryty Makarego, był fakt, że w XVII w., w czasach metropolity unickiego Hipacego Pocieja, który najprawdopodobniej był sprawcą powstania falsyfikatu w 1605 r., monaster św. Trójcy $\mathrm{w}$ Wilnie należał do unitów i był przedmiotem permanentnego sporu z prawosławnymi. Umieszczenie archimandryty wileńskiego w tym dokumencie sugero-

33 J. Fijałek, Opisy Wilna aż do połowy wieku XVII-go, „Ateneum Wileńskie” 1924, R. 2, nr 5-6, s. $142-143$.

34 „Царкоунае слова”, nr 19 (257), 207, s. 4; А. А. Мелников, Путь непечален, Минск 1992, s. 195.

$35 \mathrm{O}$ nieautentyczności listu świadczy zarówno czas $\mathrm{w}$ jakim rzekomo miał być napisany oraz nazwiska i tytulatura jego sygnatariuszy. Wymieniany w podpisach Aleksander Sołtan, nie mógł w rzeczywistości podpisać się pod tym listem, bowiem jak wiadomo z dokumentów 14 marca 1476 r. przebywał wraz z królem Kazimierzem Jagiellończykiem na terenie Prus Królewskich, a zatem kilkaset kilometrów od Wilna. Z kolei wymieniony jako pierwszy spośród bojarów prawosławnych, Iwan Chodkiewicz, został nazwany m.in. marszałkiem ziemskim litewskim, którym nigdy nie był. Szerzej o argumentach w sprawie nieautentyczności listu do papieża Sykstusa IV zob.: L. Korczak, W sprawie litewskich zwolenników unii kościelnej w drugiej połowie XV wieku, [w:] Polska i jej sasiedzi w późnym średniowieczu, red. K. Ożóg i S. Szczur, Kraków 2000, s. 323-332. 
wałoby, że już w XV w. w monasterze obecne były tendencje unijne i XVII-wieczny spór o monaster powinien być ostatecznie rozstrzygnięty na korzyść Kościoła unickiego ${ }^{36}$.

Do końca XV w. monaster św. Trójcy osiągnął status najważniejszego monasteru prawosławnego w Wilnie, a w wieku XVI - powiększając swój dorobek duchowy, intelektualny i materialny - wyrósł na jeden z najważniejszych monasterów prawosławnych w Wielkim Księstwie Litewskim, mających wpływ na położenie prawosławia na terytorium całego państwa.

\section{Three Vilnius martyrs and the beginning of the Holy Trinity Monastery in Vilnius}

\section{Summary}

The Holy Trinity Monastery in Vilnius was presumably founded in the middle of the 14th century thanks to the second wife of Duke Olgierd, Duchess Julianna Twerska. The Monastery's foundation was evoked by death of the so called Three Vilnius Martyrs: Antoni, Jan and Eustachy. They were put to death between January and December 1347, and the monastery was funded at the place of their execution.

A connection between the foundation of the Holy Trinity Monastery in Vilnius and death of three Vilnius martyrs is very strong. It should be understood not only in religious but also political terms. Antoni, Jan and Eustachy were tortured to death because they refused to adjust to external conditions at Olgierd's pagan court. When the Grand Duchy of Lithuania was at war with the Grand Duchy of Moscow, the cult of three Orthodox martyrs from Vilnius could openly threaten Duke Olgierd. For this reason, he attempted in the following years to refresh relations with the Moscow State and Byzantium, as well as regulate a status of Orthodox population living in his country. Thus the canonization of the Vilnius martyrs served this purpose as well. The foundation of the Holy Trinity Monastery was a confirmation of a new official policy being pursued by the GDL towards Orthodox religion.

As early as in the 15th century, the Holy Trinity Monastery in Vilnius played a significant role in the capital city itself and within the whole territory of the GDL.

36 J. Fijałek, Los unii florenckiej w Wielkim Księstwie Litewskim za Kazimierza Jagiellończyka, „Sprawozdania z czynności i posiedzeń PAU”, t. 33, 1934, s. 24; zob. L. Korczak, op. cit., s. 327. 
At the end of the 15th century, the Vilnius Monastery's Archimandrite was Makary, who was elected Kiev Metropolitan in 1494.

\section{Три виленские мученики и начала монастыря св. Тройцы во Вильнюсе}

\section{Резюме}

Монастырь св. Тройцы во Вильнюсе наиболее вероятно был заложен в середине XIV века, слишком делом второй жены князя Ольгерда княжны Юлианы. В основе заложения монастыря легла смерть наз. трёх, Антона, Иоанна и Евстахия. Убили их среди января и декабря 1347 года, а к месту их казни учредили монастырь.

Связь заложения монастыря св. Тройцы во Вильнюсе со смертью трёх вильнюсских мучеников очень сильная. Принадлежит его понимать, не только в религиозных категориях, но также политических. Антон, Иоанн и Евстахий были замучены, потому что отбросили возможность приспособления к внешним условиям на языческом дворе Ольгерда. В эпоху когда ВКЛ вело постоянную войну с московским государством культ трёх православных мучеников мог представлять собой для Ольгерда отпертую опасность. Потому и в следующие годы Ольгерд старался заново уложить свои связи с Москвой, и Византией и произвести регуляцию статуса православных жителей своего государства. Этой цели служила тоже канонизация вильнюсских мучеников. Учреждение монастыря св. Тройцы было подтверждением новой, официальной политики ВКЛ перед православием.

Монастырь св. Тройцы во Вильнюсе уже в XV столетии играл значащую роль в одном столичном городе как и на всём пространстве ВКЛ. На склоне столетия архимандритом вильнюсского монастыря был Макарий, выбранный в 1494 году киевским митрополитом. 